\title{
Tubular PAN/CNC Thin Film Nanocomposite (TFN) Pressure Retarded Osmosis (PRO) Membrane: Fabrication and Preliminary Evaluation in Desalination Process
}

\author{
Mehmet Emin PASAOGLU \\ Istanbul Technical University: Istanbul Teknik Universitesi \\ Ismail KOYUNCU ( $\sim$ koyuncu@itu.edu.tr) \\ Istanbul Technical University: Istanbul Teknik Universitesi
}

\section{Research Article}

Keywords: Electrospinning, Pressure Retarded Osmosis, Nanocellulose, Tubular Nanocomposite Membrane Fabrication,

Filtration

Posted Date: February 26th, 2021

DOI: https://doi.org/10.21203/rs.3.rs-245842/v1

License: (c) (1) This work is licensed under a Creative Commons Attribution 4.0 International License. Read Full License

Version of Record: A version of this preprint was published at Cellulose on July 18th, 2021. See the published version at https://doi.org/10.1007/s10570-021-04087-z. 


\section{Abstract}

The aim of this work is to fabricate tubular nanocellulose-based nanofiber pressure retarded osmosis (PRO) by electrospinning. The PRO process requires high performance, high flux, high rejection and resistant membranes under harsh conditions. Because conventional phase-inversion membranes are not sufficient to perform the required water flux. Because of this reason, alternative membrane fabrication methods need to be develop. Recently, lots of studies are carried out to fabricate strong enough nanofiber pressure retarded osmosis membranes which are resistant higher pressure pressure while providing high flux and high rejection rates. In this study, cellulose nanocrystal (CNC) added PAN nanocomposite nanofiber PRO membranes successfully fabricated by tailor made electrospinning equipment. According to the Scanning Electron Microscopy (SEM), FT-IR, Dynamic Mechanical Analysis, Porometer and Contact Angle analysis results, it is concluded that PAN and CNC provided a complete mixture and the addition of CNC increased the mechanical strength in the PAN membranes which is the crucial phenomena in PRO applications.

In this study, the newly fabricated membrane achieves a higher PRO water flux of $405.38 \mathrm{LMH}$ with using a $1 \mathrm{M} \mathrm{NaCl}$ and a DI as feed water. The corresponding salt flux is found as $2.10 \mathrm{gMH}$ which is higher than our previous study (Pasaoglu et al., 2020). The selectivity of the reversed flux represented by the ratio of the water flow to the reversed salt flux (Jw/ Js) was able to be kept as high as $193.03 \mathrm{~L} / \mathrm{g}$ for PRO operation.As far as we know, the performance of the work developed membrane in this study has shawn better performance than all PRO membranes reported in the literature previously.

\section{Introduction}

Fossil fuels have a variety of harmful environmental effects by the emission of various toxins such as sulfur oxides $\left(\mathrm{SO}_{\mathrm{x}}\right)$ and nitrogen oxides $\left(\mathrm{NO}_{\mathrm{x}}\right)$, VOCs and greenhouse gases (Zhu et al, 2010; Alami et al, 2020). Researchers are investigating the potential of generating energy from wind, sun, water, biomass and thermal heat to minimize the use of fossil fuels (Hussain et al, 2017;Tawalbeh et al, 2020; Tawalbeh et al, 2020). Electricity has recently been produced from osmotic pressure using an emerging power generation technology called pressure retarded osmosis (PRO). The mixing of two aqueous solutions of different salinities releases the Gibbs free energy of mixing process, which can be transformed to hydraulic pressure by means of a pressure retarded osmosis (PRO). The electrical power will then be produced by means of hydro-turbines (Tawalbeh et al, 2020; Jia et al, 2014; Skilhagen, 2008).

Pressure retarded osmosis (PRO) has attracted significant interest as a possible technology capable of extracting sustainable osmosis energy from salinity gradients (Cui et al, 2014; Bui and McCutheon, 2014). PRO uses a osmotic pressure difference between feed (FS) and draw solution (DS) pressurized by hydraulic pressure (Loeb, 1976; Yip et al, 2011; Kwon et al, 2021). The energy recovery method relies on placing on the draw stream a higher absolute pressure than that added to the feed stream. As a result, osmosis results in a rise in the flow rate of the high pressure stream - as long as the osmotic pressure differential $\left(\Delta \pi=\pi_{D}-\pi_{F}\right)$ exceeds the difference in the applied absolute pressure $\left(\Delta P=P_{D}-\right.$ $P_{F}$ ), where $\pi$ and $\mathrm{P}$ are the osmotic and hydraulic pressure of the fluids, and $\mathrm{D}$ and $\mathrm{F}$ are the draw and feed streams, respectively. This illustrates a classic optimization problem that is essential for the implementation of PRO units, in that higher applied pressure results in higher energy recovery per mole of solvent transfer, but also at a lower rate of solvent transfer at steady state (Manzoor et al., 2020).

The osmotic gradient will determine the quantity of energy generated, similarly as other FO applications. By merging river and seawater, the estimated osmotic energy produced worldwide is between 1750 and 2000 TWh per year, which goes over the limit one-tenth of the world's energy demand with a working pressure of 13.5 bar, equal to a $135 \mathrm{MWC}$ in a hydroelectric power plant (Sikdar, 2014; Chia et al, 2020). The average electricity generation in 2017 is about 481 TWh from biofuels, about 4197 TWh from hydraulics and about 1127 TWh from wind energy, compared to other renewable energy technologies (Tawalbeh et al, 2020; Chia et al, 2020; IEA, 2010). 
Many of the studies published in the literature is aimed at improving the viability of using PRO for generating electricity, although on small-sized systems. Figure 1 shows recent PRO research focus directions. In order to prove its feasibility in extraction of energy back in 1976 using hollow fiber membranes, Loeb et al. (1976) are experimentally testing the PRO technique. Mehta and Loeb (1978) examined the influence of osmotic pressure on high pressures. Water transport was modeled in the PRO method in 1981. In this model, the internal effects of concentration polarization were considered (Lee et al, 1981). In 1990, Loeb and his collaborators perfomed an analysis evaluating the mechanical efficiency of the continuous operation of the PRO plant. The continuous operation of the underground PRO plant and the alternating flow configuration of the terrestrial PRO plant (Loeb et al, 1990). In 2009, the Norwegian company (Statkraft) built Loeb's first design of the PRO plant in Oslo, Norway (Statkraft, 2009). The prototype of Statkraft is situated approximately $60 \mathrm{~km}$ south of Oslo, where the capital of Norway. Because of the expensive pre-treatment of river water needed and the limited capacity of electricity due to the small osmotic differential pressure between the seawater and the river, work at Statkraft terminated in December 2013 (Sarp et al, 2015). The internal concentration polarization model was developed by Xu et al. (2010) to integrate the effect of drawing solution using spiral wound FO membrane modules. Increasing water permeation across the membrane has been shown to raise the concentration of draw solution; nevertheless, the negative impact of internal polarization of concentration has also been enhanced (Xu et al, 2010). Much of the studies performed up to 2011 centered on the investigation and enhancement of membranes in PRO operations. It should be mentioned that a thin film consisting of an active layer of polyamide and a support layer of polysulfone for the PRO process was developed by Yip et al. (2011) to enhance their hydrophilic properties and improve water permeability, polydopamine was applied over the supporting layers of two suitable RO membranes (Arena et al, 2011).

Despite promising developments in PRO technology, owing to a lack of membranes with suitable high power density and acceptable durability under highly pressurized PRO operating conditions, the PRO process has yet to be commercialized (Skilhagen et al, 2008; Cai et al, 2016). For instance, because of their poor water flow and low power density, prototype commercial cellulose acetate (CTA) membranes have not been shown to be commercially viable for use in PRO (under the conditions of smaller than $1 \mathrm{~W} \mathrm{~m}^{-2}$ using river water as feed and seawater as draw solution) (Kwon et al, 2021, Song et al, 2013; Chou et al, 2012; Vos, 1966).

Apart from the recent PRO research tendency we focused on the strengthening the membrane material cope with creeping phenomena in this study. One of the most important purposes is to use less petro-chemical materials during the production of membranes, while increasing the strength in the use of the membrane in the PRO process.

We concentrate on the biocompatible approach in this study by adding cellulose nanocrystals (CNCs) to the TFC membranes based on nanofiber. Natural needle-rod fragments arising from acid hydrolysis of raw cellulose are CNCs, also known as nanocrystalline cellulose (NCC) (De Souza Lima, 2004). The amorphous segments of cellulose, consisting of cellulose fibres, lignin, waxes, etc., degrade and remain extremely crystalline as biomass is processed in a harsh acid environment (Asempour et al, 2018). Cellulose can be defined as a high molecular weight homopolymer of $\beta-1,4-l i n k e d$ anhydro-D-glucose units, irrespective of their source, in which each unit is $180^{\circ}$ corkscrew relative to its neighbors and the repeat section is commonly used as a glucose dimer known as cellobiose (Figure 2). With respect to the termini of its molecular axis, each cellulose chain has dimensional chemical asymmetry: one end is a group that is chemically reduced (i.e. hemiacetal unit) and the other end is a pendant hydroxyl unit, the nominal non-reducing end. The number of glucose units or the degree of polymerization (DP) is up to 20000 , but shorter cellulose chains may occur and are often located in the primary walls of the cells (Habibi, 2010).

Depending on the source of cellulose and the conditions of acid treatment, the size of the CNCs varies, but typically they are a few hundred nanometers long and a few nanometers in diameter (Habibi et al, 2010; Peng et al, 2011). They have a high specific density, a large specific surface area and a large negative zeta potential, as well as Young's modulus. They also have a highly reactive surface that makes them favorable for chemical functionalization due to the presence of the 
single bond -OH groups (Habibi et al, 2010; Peng et al, 2011). CNCs are biodegradable, renewable, have very low impacts on the ecosystem and are generally referred to as non-toxic and harmless particles (Habibi et al, 2010; Peng et al, 2011; Canada 2020; Kovacs et al, 2010; Roman et al, 2009; Hanif et al, 2014; Mahmoud et al, 2010; Bai et al, 2012; Li et al, 2011; Daraei et al, 2017. For a wide variety of possible uses, these appealing properties of CNCs have attracted considerable interest in PRO membrane fabrication.

Usually, two categories of membranes have been used extensively for PRO membranes. First one is the thin-film composite (TFC) membrane with selective layers on porous supports and the second one is an engineered shelled membrane developed using cellulose acetate (CA) and cellulose triacetate (CTA) (Sun and Chung et al, 2013; Lee et al, 2020). It is feasible to fabricate TFC membranes to ensure support, and selective layers have a greater flux of water than CA or CTA membranes (Gonzales et al, 2019). PRO membranes using a TFC membrane have also been studied in several researches (Lee et al, 2020) . In other experiments, Bui and McCutcheon, (2014) and Song et al. (2013) developed nanofiber-based PRO membranes with nanofiber support for polyacrylonitrile (PAN). Nanofibers are known to have a high potential for use in the development of osmotically-driven membranes due to their high porosity and low tortuosity (Bui et al, 2014; Shirazi et al, 2017; Son et al, 2018). In fact, the produced membranes achieved a power density of 21.3 W/m²@ 15.2 bar and $8.0 \mathrm{~W} / \mathrm{m}^{2} @ 11.5$ bar, when $1.06 \mathrm{M} \mathrm{NaCl}$ and $0.5 \mathrm{M} \mathrm{NaCl}$ were used as drawing solutions, respectively (Lee et al, 2020).

Mentioned studies have proved the feasibility of nanofibers for use in the production of PRO membranes with high power density. However, owing to their comparatively lower mechanical flexibility, at high hydraulic pressures in nanofiber oriented PRO membranes, the risk of membrane deformation still exists. In order to address the poor mechanical stability of nanofiber-based PRO membranes at different ratios, the mechanical stability of polyacrylonitrile (PAN) nanofiber support was enhanced by CNC composites and the nanofiber structure was controlled.

\section{Experimental}

\subsection{Materials}

Polyacrylonitrile (PAN) homopolymer (Mw=150000 Da from Sigma-Aldrich/USA) nanofiber base material and nanocellulose addition arranged as 1, 2, 5 and 10\% wt/wt. DMAc used as solvent from AK-KIM Chemicals/Turkey. Tailor made tubular electrospinning device was used for fabrication nanofiber membranes over hollow braided rope and crystal nanocellulose (CNC) brought from BGB Company/Canada and hollow braided rope from Kord Technical Ropes/Turkey.

\subsection{Fabrication of nanofibrous tubular mats on hollow braided rope}

The configuration of the multi-nozzle bottom-up electrospinning system used in this research is shown in Fig. 5.3. A voltage adjuster between the range of $0-40 \mathrm{kV}$ was used to change the voltage. The distance between the nozzle and the collector was also manually controlled to achieve a uniform fiber formation and fiber layers without any beads. In addition, a heat treatment system was used at a specified temperature and time on tubular nanofiber membranes. The PAN polymer with $16 \%$ DMAc solvent was dissolved by overnight stirring. For each condition, the spinning shaft speed was kept constant. The solution mixture was filled into a syringe and injected at a defined flow rate into the nozzle system. A hollow braided rope mounted on thin cylindrical steel attached to the spinning rod was coated with nanofibers. Each production step is shown in Figure 3.

\subsection{Fabrication of thin film nanocomposite (TFN) tubular cnc pressure retarded osmosis membranes}

Fabricated support nanofiber membranes are primarily immersed in purified water for at least one hour. Aqueous $\mathrm{m}$ phenylenediamine (MPD) solution and trimesochloride (TMC) solution are then applied in hexane. In order to remove air bubbles nitrogen gas applied to the MPD solution. Interfacial polymerization reaction scheme is shown in Figure 4. 
Fabricated membranes are preserved in distilled water after post-treatment. A schematic view of the manufacturing steps as shown in Figure 5.

Thin film nanocomposite membrane coatig procedure is given in Table 1.

Table 1. Thin film nanocomposite membrane coating procedure.

\begin{tabular}{|llllll|}
\hline $\begin{array}{l}\text { MPD } \\
\text { Concentration }\end{array}$ & MPD Duration & Air Dry & TMC Concentration & $\begin{array}{l}\text { TMC } \\
\text { Duration }\end{array}$ & Oven Dry @ 70 ${ }^{\circ} \mathrm{C}$ \\
\hline $3.5 \%$ & $15 \mathrm{~min}$. & $1 \mathrm{~min}$. & $0.15 \%$ & $4 \mathrm{~min}$. & $5 \mathrm{~min}$. \\
\hline
\end{tabular}

\subsection{Pressure retarded osmosis setup}

For the experiment, water flow and reverse leakage of salt have been measured. Figure 6 demonstrates the size of the TFC membranes produced from the electrospun-PAN / CNC based PRO system. Pneumatic PE hose with an internal diameter of $6 \mathrm{~mm}$ was used as a housing in cross-flow experiments. The holes at both ends of the hose is filled with heavy duty industry scale silicone. The concentrate was circulated via the shell-side of the membrane, while the feed solution was contacted through the lumen-side.

The salt concentration changes in both the feed and draw solutions measured by EC meter. Feed side weight changes were recorded with digital balance. As a consequence of water extract from the feed solution side, the initial concentration of drawing solution decreases. PRO tests were performed using $1 \mathrm{M} \mathrm{NaCl}$ as draw and distilled water as the feed solution under standard room temperature. Fabricated membrane modules are shown in Figure 6. Membrane modules have been developed to facilitate the study of water and salt fluxes in cross-flow system. A shematic draw of the PRO test setup is shown in Figure 7.

\section{Results And Discussion}

\subsection{Characterization of tubular nanofibrous membrane}

\subsubsection{SEM analysis of nanofibrous support and thin film nanocomposite (TFN) layer}

The morphology of nanofiber membranes and thin film nanocomposite (TFN) layer were described by the FEI Quanta FEG 250/Czech Republic equipment. Nanofiber membranes coated with Gold and Palladium (Au-Pd) with a thickness of nearly 3-4 nm using Quorum SC7620 equipment. Surface morphology and fiber thickness of the nanofiber membranes are given for support layer in Figure 8, surface of thin film composite (TFN) layer in Figure 9 and cross section of TFN layer in Figure 10.

\subsubsection{Determination of pore size}

Using the Quantachrome 3G Porometer, the pore sizes were measured.For porometry measurements, the membranes were split and pinced on both ends. On the basis of the total area, the pore sizes were calculated. Quantachrome Porofil was used as a porometry weighting agent with a low surface impedance of 16 dynes/cm (Quantachrome Ins., Florida , USA).

It is commonly recognized that decreasing the concentration of the solvent or the molecular weight can decrease the fiber diameter due to lower viscosity (Tan et al, 2005). The viscosity of the solution produces an anti-electrostatic repulsion force responsible for the stretching and thinning of the solution jet. Unlike several other parameters, it has repeatedly been shown that higher viscosity results in higher fiber diameters, irrespective of the material used. 
In effect, the diameter and thickness relate to the distribution of the pore size and the shape of the pore. The electrospinning polymer does not have adequate entanglements to create stability at a very low viscosity of the polymer solution, which leads to droplet formation (Murthe et al, 2019). In Figure 11, it reveals that increased volume of CNC addition to the PAN polymer solution, fabricated nano-composite nanofiber membranes display a diminishing porosity pattern (Pasaoglu and Koyuncu, in press).

\subsubsection{Dynamic mechanical analysis}

Dynamic mechanical analysis (DMA) of fabricated membranes are performed for different CNC additon ratios using SEIKO Dynamic mechanical spectrometer Extar 6100/Japan. DMA can be used for research into the viscoelastic behavior of the nanofibrous membranes specimens. The DMA is capable of applying a given oscillatory force to a test specimen, and the strain or displacement is subsequently evaluated.

Before testing, the produced membranes were taken by stripping from the tubular hollow braided rope and the measurements were made in the test equipment similar as the measurement of flat-sheet nanofiber membranes. Figure 12 shows that an increasing amount of CNC is being increased for youngs' modulus of engineered membranes, which is a critical parameter for resistance to high pressure. The higher viscosity of the polymer solution at higher CNC is the factor for this efficiency improvement.

\subsubsection{Fourirer-transform infrared spectroscopy (FTIR) of the fabricated membranes}

Fourier-transform infrared spectroscopy (FTIR) has been identified for the dry support layer membrane in order to check the chemical composition of the organic molecules and the potential structural modifications that occur by CNC in addition to the PAN process.

The FTIR spectrum was measured using the Perkin Elmer Spectrum 100 FTIR Spectrometer/USA (650-4,000 cm-1) absorption mode. Figure 13 reveals that the FTIR range of fabricated membranes proves that with a rise in crystal nanocellulose, the $\mathrm{C}-\mathrm{N}$ group reacted with the cellulose group and disappeared at 1,664.58 cm-1 point.

The peak of CNC was present at 1,620 cm-1 in the spectrum due to $\mathrm{C}=0$ interconnectivity, which is one characteristic of lignin and lignin / hemicellulose (Asrofi et al., 2017). Figure 13 also indicates that the PAN spectrum value of 1,452 cm-1 is the normal $\mathrm{C}-\mathrm{H}$ stretching methylene band characteristic, and the $\mathrm{C}-\mathrm{H}$ stretching vibration is the typical vibration of 2,923 cm-1 (Jin et al, 2018).

\subsubsection{Contact angle analysis of the fabricated membranes}

The hydrophilicity of fabricated CNC/PAN nanocomposite membranes are measured using a goniometer (Attension-KSVEspoo/Finland) with $2 \mu \mathrm{L}$ of DI water droplet. 10 images are obtained from three different points on different sides of the membrane, and the mean average contact angle is recorded. The range is $0^{\circ}-180^{\circ}$ and the magnitude of the difference is $\pm 0.1^{\circ}$. According to the findings, the contact angle of the fabricated membranes indicates a dramatic decrease in the growing amount of CNC to PAN polymer solution, which tends to increase membrane water flux in the process shown in Figure 14. According to literature studies Voisin et al. (2017), Cheng et al. (2017), Bai et al, (2017) the increasing amount of $\mathrm{CNC}$ helps reduce the value of the membrane contact angle.

\section{PRO test results}

The membrane is PRO-oriented while the drawing solution is placed against the active layer and the feed solution is positioned against the support layer.Under the same conditions, 2\% CNC added PAN nanocomposite nanofiber TFC-PRO membranes perform higher water flux which is shown in Fig. 15. 
The addition of CNC in PAN polymer solution obviously allowed the flux increase in the membranes. Although a very high flux was seen on the membrane with $5 \% \mathrm{CNC}$ additive, this flux value decreased rapidly. After 60 minutes of operation, most of the fabricated membranes considerably sustain their original flux.

Reverse salt flux indicates salt leakage from the PRO membrane to the side of the feed solution. For such a while of salt leakage, the draw side is diluted, leading to a reduced osmotic pressure difference. Thus, although ideal for the development of PRO membranes, it is important to have the lowest reverse salt flux and higher water flux. In this research, it can be easily seen in Figure 16, where 1\% CNC added PAN nanocomposite nanofiber TFC membranes provide the best results.

A further distinction was made between this research and the literature for the application of PRO in Table 2 in terms of water flux and reverse salt flux of membranes. The results show that fabricated membranes in this study have one of the highest $\mathrm{J}_{\mathrm{W}} / \mathrm{J}_{\mathrm{S}}$ ratios in the literature.

Table 2. Comparison of PRO performance of various TFC membranes with DI water as feed solutions

\begin{tabular}{|c|c|c|c|c|c|c|}
\hline Membrane & $\begin{array}{l}\text { Water flux, } \\
\mathrm{J}_{W} \text { (PRO) } \\
(\mathrm{LMH})\end{array}$ & $\begin{array}{l}\text { Reverse salt } \\
\text { flux, Js (PRO) } \\
(\mathrm{gMH})\end{array}$ & $J_{s} / J_{W}(g / L)$ & $J_{w} / J_{s}(g / L)$ & $\begin{array}{l}\text { Draw } \\
\text { solution }\end{array}$ & Ref. \\
\hline $\begin{array}{l}\text { PAN/CNC TFN } \\
\text { membrane ( } 2 \% \\
\text { CNC) }\end{array}$ & 405.38 & 2.10 & 0.00518 & 193.03 & $\begin{array}{l}1.0 \mathrm{M} \\
\mathrm{NaCl}\end{array}$ & $\begin{array}{l}\text { This } \\
\text { study }\end{array}$ \\
\hline $\begin{array}{l}\text { PAN/CNC } \\
\text { nanocomposite } \\
\text { TFC membrane } \\
\text { ( } 5 \% \text { CNC) }\end{array}$ & 300 & 1.50 & 0.005 & 200 & $\begin{array}{l}1.0 \mathrm{M} \\
\mathrm{NaCl}\end{array}$ & $\begin{array}{l}\text { (Pasaoglu } \\
\text { et al, } \\
2020 \text { ) }\end{array}$ \\
\hline $\begin{array}{l}\text { FO flat-sheet } \\
\text { membrane on } \\
\text { sPSU }\end{array}$ & 313 & 5.30 & 0.017 & 58.8 & $\begin{array}{l}1.0 \mathrm{M} \\
\mathrm{NaCl}\end{array}$ & $\begin{array}{l}\text { (Voisin et } \\
\text { al, 2017) }\end{array}$ \\
\hline CTA-ES HTI & 8.10 & 20.03 & 2.47 & 0.4 & $\begin{array}{l}1.0 \mathrm{M} \\
\mathrm{NaCl}\end{array}$ & $\begin{array}{l}\text { (Voisin et } \\
\text { al, 2017) }\end{array}$ \\
\hline TFC-ES HTI & 19.31 & 14.78 & 0.765 & 1.3 & $\begin{array}{l}1.0 \mathrm{M} \\
\mathrm{NaCl}\end{array}$ & $\begin{array}{l}\text { (Voisin et } \\
\text { al, 2017) }\end{array}$ \\
\hline $\begin{array}{l}\text { Electrospun- } \\
\text { PSf-based TFC } \\
\text { with PET layer- } \\
\text { before adding } \\
\text { SDS }\end{array}$ & 26 & $2.26 \times 10^{-3}$ & 0.00008 & 0.01150 & $\begin{array}{l}1.5 \mathrm{M} \\
\mathrm{NaCl}\end{array}$ & $\begin{array}{l}\text { (Bui et al, } \\
\text { 2011) }\end{array}$ \\
\hline $\begin{array}{l}\text { Electrospun- } \\
\text { PSf-based TFC } \\
\text { with PET layer- } \\
\text { after adding } \\
\text { SDS }\end{array}$ & 3.6 & $4.62 \times 10^{-2}$ & 0.0013 & 0.072 & $\begin{array}{l}1.5 \mathrm{M} \\
\mathrm{NaCl}\end{array}$ & $\begin{array}{l}\text { (Bui et al, } \\
\text { 2011) }\end{array}$ \\
\hline $\begin{array}{l}\text { Electrospun- } \\
\text { PSf-based TFC } \\
\text { without PET } \\
\text { layer-before } \\
\text { adding SDS }\end{array}$ & 24.0 & 8.63 & 0.359 & 2.78 & $\begin{array}{l}1.5 \mathrm{M} \\
\mathrm{NaCl}\end{array}$ & $\begin{array}{l}\text { (Bui et al, } \\
\text { 2011) }\end{array}$ \\
\hline
\end{tabular}

Table 2 (continued) : Comparison of PRO performance of various TFC membranes with DI water as feed solutions 


\begin{tabular}{|c|c|c|c|c|c|c|}
\hline Membrane & $\begin{array}{l}\text { Water flux, } \\
J_{W} \text { (PRO) } \\
\text { (LMH) }\end{array}$ & $\begin{array}{l}\text { Reverse } \\
\text { salt flux, } \mathrm{J}_{\mathrm{s}} \\
\text { (PRO) } \\
\text { (gMH) }\end{array}$ & $\begin{array}{l}J_{s} / J_{W} \\
(g / L)\end{array}$ & $\begin{array}{l}J_{w} / J_{s} \\
(g / L)\end{array}$ & $\begin{array}{l}\text { Draw } \\
\text { solution }\end{array}$ & Ref. \\
\hline $\begin{array}{l}\text { Electrospun-PSf-based TFC without PET layer- } \\
\text { after adding SDS }\end{array}$ & 86.1 & 36.40 & 0.422 & 25.32 & $\begin{array}{l}1.0 \mathrm{M} \\
\mathrm{NaCl}\end{array}$ & $\begin{array}{l}\text { (Bui et } \\
\text { al, } \\
2011 \text { ) }\end{array}$ \\
\hline $\begin{array}{l}\text { FO flat sheet membrane on cellulose ester } \\
\text { substrate }\end{array}$ & 128.8 & 19.40 & 0.15 & 6.67 & $\begin{array}{l}2.0 \mathrm{M} \\
\mathrm{NaCl}\end{array}$ & $\begin{array}{l}\text { (Ong et } \\
\text { al, } \\
2015)\end{array}$ \\
\hline $\begin{array}{l}\text { FO flat sheet membrane on sulfonated } \\
\text { polyphenylenesulfone ( } 2.5 \text { mole \% direct } \\
\text { sulfonation) supports }\end{array}$ & 54 & 8.80 & 0.163 & 6.13 & $\begin{array}{l}2.0 \mathrm{M} \\
\mathrm{NaCl}\end{array}$ & $\begin{array}{l}\text { (Widjojo } \\
\text { et al, } \\
2013 \text { ) }\end{array}$ \\
\hline $\begin{array}{l}\text { FO flat sheet membrane on PES/sPSf } \\
\text { supports }\end{array}$ & 47.5 & 12.40 & 0.261 & 3.83 & $\begin{array}{l}2.0 \mathrm{M} \\
\mathrm{NaCl}\end{array}$ & $\begin{array}{l}\text { (Wang } \\
\text { et al, } \\
2012 \text { ) }\end{array}$ \\
\hline
\end{tabular}

\section{Conclusions}

Thin film nanocomposite (TFN) CNC added PRO membranes were successfully fabricated with tailor-made electrospinning machine. During operation, fabricated PRO membranes fulfill the needs of higher pressures. Increasing the amount of CNC has an impressive impact on the youngs' modulus that makes the PRO membrane stronger. FTIR spectra indicate that similar groups reacted with cellulose groups and modified the spectra, and it was observed that increasing the amount of CNC made the membrane more hydrophilic. Apart from the FTIR spectrum findings, it can be inferred that CNC content is compliant with PAN polymers. Morphology tests conducted using SEM equipment have shown that increasing the amount of CNC does not have a drastic impact on membrane formation until the addition of $10 \%$ of CNC. With regard to PRO efficiency measurements, the $\% 2 \mathrm{CNC}$ addition to the PAN polymer matrix gives superior water flux and the lowest reversed salt flux. Comparing this research with the literature, it can be easily shown that PAN/CNC nanocomposite TFN membranes provide maximum water flux and one of the lowest inverted salt flux values.

\section{Declarations}

\section{Acknowledgment}

The authors are grateful to Istanbul Technical University Scientific Research Council (BAP) (Project No:MGA-2017-40885).

\section{References}

1. A. Hussain, S.M. Arif, M. Aslam, Emerging renewable and sustainable energy technologies: state of the art, Renew. Sust. Energ. Rev. 71 (2017)12-28.

2. A. Shirazi, M. Mahdi, A. Kargari, S. Ramakrishna, J. Doyle, M. Rajendrian, P. Babu, Electrospun membranes for desalination and water/wastewater treatment: a comprehensive review, J. Membr. Sci. Res. 3 (2017)209-227.

3. A.H. Alami, A. Abu Hawili, M. Tawalbeh, R. Hasan, L. Al Mahmoud, S. Chibib, et al. Materials and logistics for carbon dioxide capture, storage and utilization, Sci. Total Environ. 717 (2020)137221.

4. B.L. Peng, N. Dhar, H.L. Liu, K.C. Tam, Chemistry and applications of nanocrystalline cellulose and its derivatives: a nanotechnology perspective, Can. J. Chem. Eng. 89 (2011) 1191-1206. 
5. C. Lee, S.H. Chae, E. Yang, S. Kim, J.H. Kim, I.S. Kim, A comprehensive review of the feasibility of pressure retarded osmosis: Recent technological advances and industrial efforts towards commercialization, Desalination 491 (2020)114501.

6. Canada, N. (2020, July 16). Government of Canada. Retrieved November 15, 2020, from http://www.nrcan.gc.ca/forests/industry/products-applications/13349

7. D. Li, H. Wang, Recent developments in reverse osmosis desalination membranes, J. Mater. Chem. 20 (2010)45514566.

8. F. Asempour, D. Emadzadeh, T. Matsuura, B. Kruczek, Synthesis and characterization of novel cellulose nanocrystalsbased thin film nanocomposite membranes for reverse osmosis applications, Desalination 439 (2018)179-187.

9. G.D. Mehta, S. Loeb, Performance of permasep B9 and B10 membranes in various osmotic regions and at high osmotic pressures, J. Membr. Sci. 4 (1978)335-349.

10. H. Bai, X. Wang, Y. Zhou, L. Zhang, Preparation and characterization of poly(vinylidene fluoride) composite membranes blended with nano-crystalline cellulose, Prog. Nat. Sci.: Mater. Int. 22 (2012)250-257.

11. H. Manzoor, M.A. Selam, F.B. Abdur Rahman, S. Adham, M. Castier, A. Abdel-Wahab, A tool for assessing the scalability of pressure-retarded osmosis (PRO) membranes, Renew. Energy 149 (2020)987-999.

12. H. Voisin, L. Bergström, P. Liu, A.P. Mathew, Nanocellulose-based materials for water purification, Nanomaterials (Basel)7(3)(2017)57.

13. IEA, O. (2010). Electricity Information 2010. International Energy Agency, Paris Cedex, France.

14. J.T. Arena, B. McCloskey, B.D. Freeman, J.R. McCutcheon, Surface modification of thin film composite membrane support layers with polydopamine: enabling use of reverse osmosis membranes in pressure retarded osmosis, J. Membr. Sci. 375 (2011)55-62.

15. K. Lee, R.W. Baker, H. Lonsdale, Membrane for power generation by pressure retarded osmosis, J. Membr. Sci. 8 (1981)141-171.

16. K.A. Mahmoud, J.A. Mena, K.B. Male, S. Hrapovic, A. Kamen, J.H.T. Luong, Effect of surface charge on the cellular uptake and cytotoxicity of fluorescent labeled cellulose nanocrystals, ACS Appl. Mater. Interfaces 2 (2010)2924-2932.

17. K.D. Vos, F.O. Burris, R.L. Riley, Kinetic study of the hydrolysis of cellulose acetate in the pH range of 2-10, J. Appl. Polym. Sci. 10 (1966)825-832.

18. K.Y. Wang, T.S. Chung, G. Amy, Developing thin-filmcomposite forward osmosis membranes on the PES/SPSf substrate through interfacial polymerization, AlChE J. 58 (2012) 770-781.

19. L.M. Bai, N. Bossa, F.S. Qu, J. Winglee, G.B. Li, K. Sun, H. Liang, M.R. Wiesner, Comparison of hydrophilicity and mechanical properties of nanocomposite membranes with cellulose nanocrystals and carbon nanotubes, Environ. Sci. Technol. 51 (2017) 253-262.

20. M. Asrofi, H. Abral, A. Kasim, A. Pratoto, XRD and FTIR studies of nanocrystalline cellulose from water hyacinth (Eichornia crassipes) fiber, J. Metastable Nanocryst. Mater. 29 (2017)9-16.

21. M. Roman, S. Dong, A. Hirani, Y.W. Lee, (2009) Cellulose nanocrystals for drug delivery. In: K.J. Edgar, T. Heinze, C. Buchanan. editors. Polysaccharide Materials: Performance by Design, ACS Symposium Series 1017. Washington, DC: American Chemical Society; 81-91.

22. M. Son, J. Bae, H. Park, H. Choi, Continuous thermal-rolling of electrospun nanofiber for polyamide layer deposition and its detection by engineered osmosis, Polymer 145 (2018)281-285.

23. M. Tawalbeh, A. Al-Othman, K. Singh, I. Douba, D. Kabakebji, M. Alkasrawi, Microbial desalination cells for water purification and power generation: a critical review, Energy 209 (2020)118493.

24. M. Tawalbeh, A. Al-Othman, N. Abdelwahab, A.H. Alami, A.G. Olabi, Recent developments in pressure retarded osmosis for desalination and power generation, Renew. Sust. Energ. Rev. (2020)110492. 
25. M.E. Pasaoglu, I. Koyuncu. (in press). Fabrication, Characterization and Application of Flat Sheet PAN/CNC Nanocomposite Nanofiber Pressure Retarded Osmosis (PRO) Membrane, Desalin. Water Treat.

26. M.M. de Souza Lima, R. Borsali, Rodlike cellulose microcrystals: structure, properties, and applications, Macromol. Rapid Commun. 25 (2004)771-787.

27. N. Widjojo, T.S. Chung, M. Weber, C. Maletzko, V. Warzelhan, A sulfonated polyphenylenesulfone (sPPSU) as the supporting substrate in thin film composite (TFC) membranes with enhanced performance for forward osmosis (FO), Chem. Eng. J. 220 (2013) 15-23.

28. N.N. Bui, J.R. McCutcheon, Nanofiber supported thin-film composite membrane for pressure-retarded osmosis, Environ. Sci. Technol. 48 (2014)4129-4136.

29. N.N. Bui, M.L. Lind, E.M.V. Hoek, J.R. McCutcheon, Electrospun nanofiber supported thin film composite membranes for engineered osmosis, J. Membr. Sci. 385-386 (2011)10-19.

30. N.Y. Yip, A. Tiraferri, W.A. Phillip, J.D. Schiffman, L.A. Hoover, Y.C. Kim, M. Elimelech, Thin-film composite pressure retarded osmosis membranes for sustainable power generation from salinity gradients, Environ. Sci. Technol. 45 (2011)4360-4369.

31. P. Daraei, N. Ghaemi, H.S. Ghari, An ultra-antifouling polyethersulfone membrane embedded with cellulose nanocrystals for improved dye and salt removal from water, Cellulose 24 (2017)915-929.

32. Q. Cheng, D. Ye, C. Chang, L. Zhang, Facile fabrication of superhydrophilic membranes consisted of fibrous tunicate cellulose nanocrystals for highly efficient oil/water separation, J. Membr. Sci. 525 (2017)1-8.

33. R.C. Ong, T.S. Chung, J.S. de Wit, B.J. Helmer, Novel cellulose ester substrates for high performance flat-sheet thinfilm composite (TFC) forward osmosis (FO) membranes, J. Membr. Sci. 473 (2015)63-71.

34. R.M. El Khaldi, M.E. Pasaoglu, S. Guclu, Y.Z. Menceloglu, R. Ozdogan, M. Celebi, M.A. Kaya, I. Koyuncu, Fabrication of high-performance nanofiber-based FO membranes, Desal. Water Treat. 147 (2019) 56-72.

35. R.R. Gonzales, M.J. Park, T.-H. Bae, Y. Yang, A. Abdel-Wahab, S. Phuntsho, H.K. Shon, Melamine-based covalent organic framework-incorporated thin film nanocomposite membrane for enhanced osmotic power generation, Desalination 459 (2019)10-19.

36. S. Chou, R. Wang, L. Shi, Q. She, C. Tang, A.G. Fane, Thin-film composite hollow fiber membranes for pressure retarded osmosis (PRO) process with high power density, J. Membr. Sci. 389 (2012)25-33.

37. S. H. Tan, R. Inai, M. Kotaki, S. Ramakrishna, Systematic parameter study for ultra-fine fiber fabrication via electrospinning process, Polymer 46 (2005)6128.

38. S. Li, Y. Gao, H. Bai, L. Zhang, P. Qu, L. Bai, Preparation and characterization of polysulfone dialysis composite membranes with nanocrystalline cellulose, Bioresources 6 (2011)1670-1680.

39. S. Loeb, Production of energy from concentrated brines by pressure-retarded osmosis : I. Preliminary technical and economic correlations. J. Membr. Sci. 1 (1976) 49-63.

40. S. Loeb, T. Honda, M. Reali, Comparative mechanical efficiency of several plant configurations using a pressureretarded osmosis energy converter, J. Membr. Sci. 51(1990) 323-335.

41. S. Sarp, Z. Li, J. Saththasivam, Pressure Retarded Osmosis (PRO): past experiences, current developments, and future prospects, Desalination 389 (2015)2-14.

42. S.E. Skilhagen, J.E. Dugstad, R.J. Aaberg, Osmotic power-power production based on the osmotic pressure difference between waters with varying salt gradients, Desalination 220 (2008)476-482.

43. S.J. Kwon, K. Park, D.Y. Kim, M. Zhan, S. Hong, J.H. Lee, High-performance and durable pressure retarded osmosis membranes fabricated using hydrophilized polyethylene separators, J. Membr. Sci. 619 (2021)118796.

44. S.K. Sikdar, An E-Conversation with Prof. Neal Chung, Clean Technol. Environ. Policy, 16 (8) (2014)1481-1485. 
45. S.P. Sun, T.S. Chung, Outer-selective pressure-retarded osmosis hollow-fiber membranes from vacuum-assisted interfacial polymerization for osmotic power generation, Environ. Sci. Technol. 47 (2013)13167-13174.

46. S.S. Murthe, M.S.M. Saheed, V. Perumal, M.S.M. Saheed, N.M. Mohamed, (2019) Electrospun Nanofibers for Biosensing Applications. In: S.C.B. Gopinath, T. Lakshmipriya. Editors. Nanobiosensors for Biomolecular Targeting, Oxford, UK: Elsevier; 253-267.

47. S.X. Jin, J.L. Yu, Y.S. Zheng, W.Y. Wang, B.J. Xin, C.-W. Kan, Preparation and characterization of electrospun PAN/PSA carbonized nanofibers: experiment and simulation study, Nanomaterials (Basel) 8(10)(2018)821.

48. Statkraft, Crown Princess of Norway to open the world's first osmotic power plant, Press Release Crown Princess to Open World's First Osmotic Power Plant (2009).

49. T. Cai, X. Li, C. Wan, T.S. Chung, Zwitterionic polymers grafted poly(ethersulfone) hollow fiber membranes and their antifouling behaviors for osmotic power generation, J. Membr. Sci., 497 (2016)142-152.

50. T. Kovacs, V. Naish, B. O'Connor, C. Blaise, F. Gagné, L. Hall, V. Trudeau, P. Martel, An ecotoxicological characterization of nanocrystalline cellulose (NCC), Nanotoxicology 4 (2010)255-270.

51. W.Y. Chia, S.R. Chia, K.S. Khoo, K.W. Chew, P.L. Show, Sustainable membrane technology for resource recovery from wastewater: Forwards osmosis and pressure retarded osmosis, J. Water Process. Eng. (2020)101758.

52. X. Song, Z. Liu, D.D. Sun, Energy recovery from concentrated seawater brine by thin-film nanofiber composite pressure retarded osmosis membranes with high power density, Energy Environ. Sci. 6 (2013)1199-1210.

53. X.G. Zhu, S.P. Long, D.R. Ort, Advanced technology paths to global climate stability: energy for a greenhouse planet, Annu. Rev. Plant Biol. 61 (2010)235-261.

54. Y. Cui, X.Y. Liu, T.S. Chung, Enhanced osmotic energy generation from salinity gradients by modifying thin film composite membranes, Chem. Eng. J. 242 (2014)195-203.

55. Y. Habibi, L.A. Lucia, O. Rojas, Cellulose Nanocrystals: Chemistry, Self-Assembly, and Applications, Chem. Rev. 110 (2010)3479-3500.

56. Y. Xu, X. Peng, C.Y. Tang, Q.S. Fu, S. Nie, Effect of draw solution concentration and operating conditions on forward osmosis and pressure retarded osmosis performance in a spiral wound module, J. Membr. Sci. 348 (2010)298-309.

57. Z. Hanif, F.R. Ahmed, S.W. Shin, Y.-K. Kim, S.H. Um, Size- and dose-dependent toxicity of cellulose nanocrystals (CNC) on human fibroblasts and colon adenocarcinoma, Colloids Surf. B: Biointerfaces 119 (2014)162-165.

58. Z. Jia, B. Wang, S. Song, Y. Fan, Blue energy: current technologies for sustainable power generation from water salinity gradient, Renew. Sust. Energ. Rev. 31 (2014)91-100.

\section{Figures}




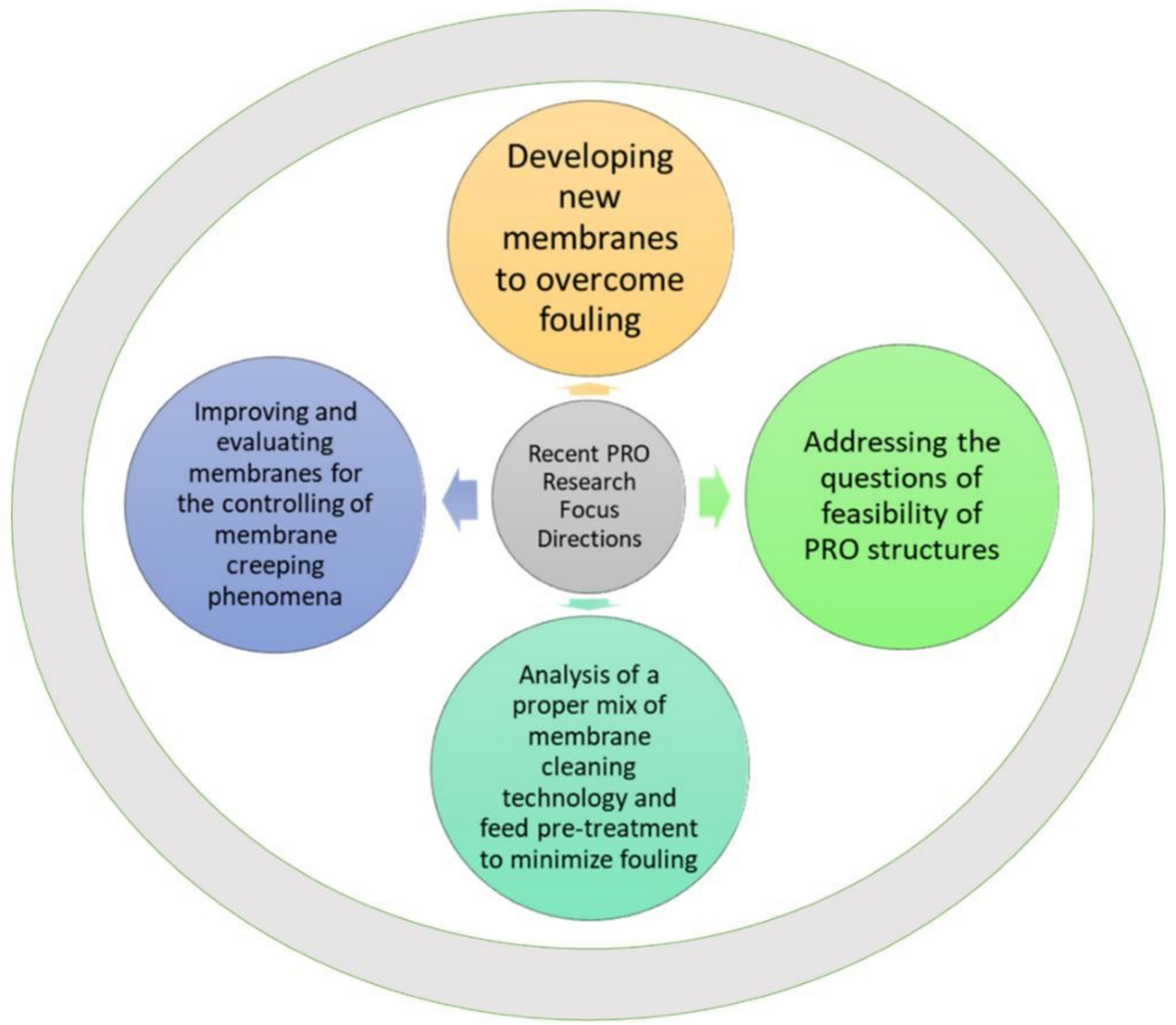

Figure 1

Recent PRO research focus directions (Redrawn from Tawalbeh et al, 2020).

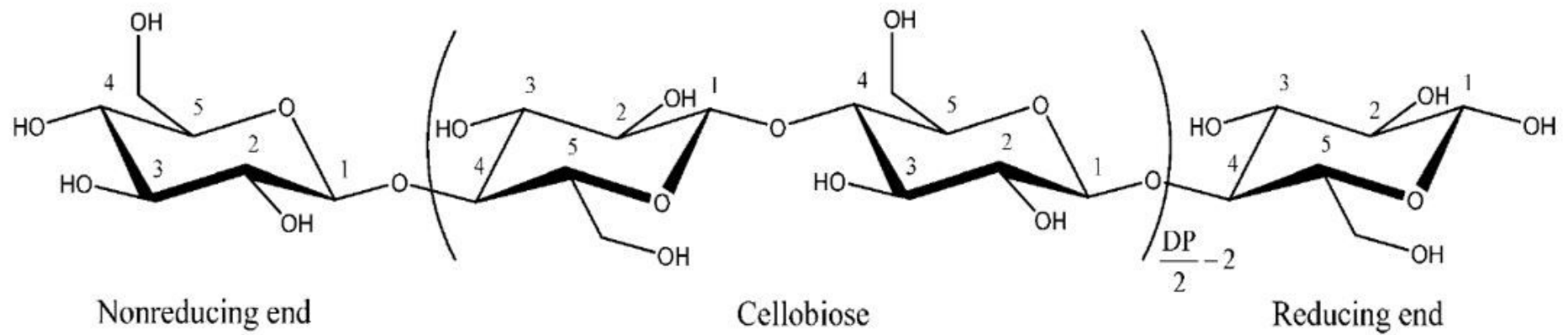

Figure 2 
Chemical composition of cellulose (Habibi et al, 2010).
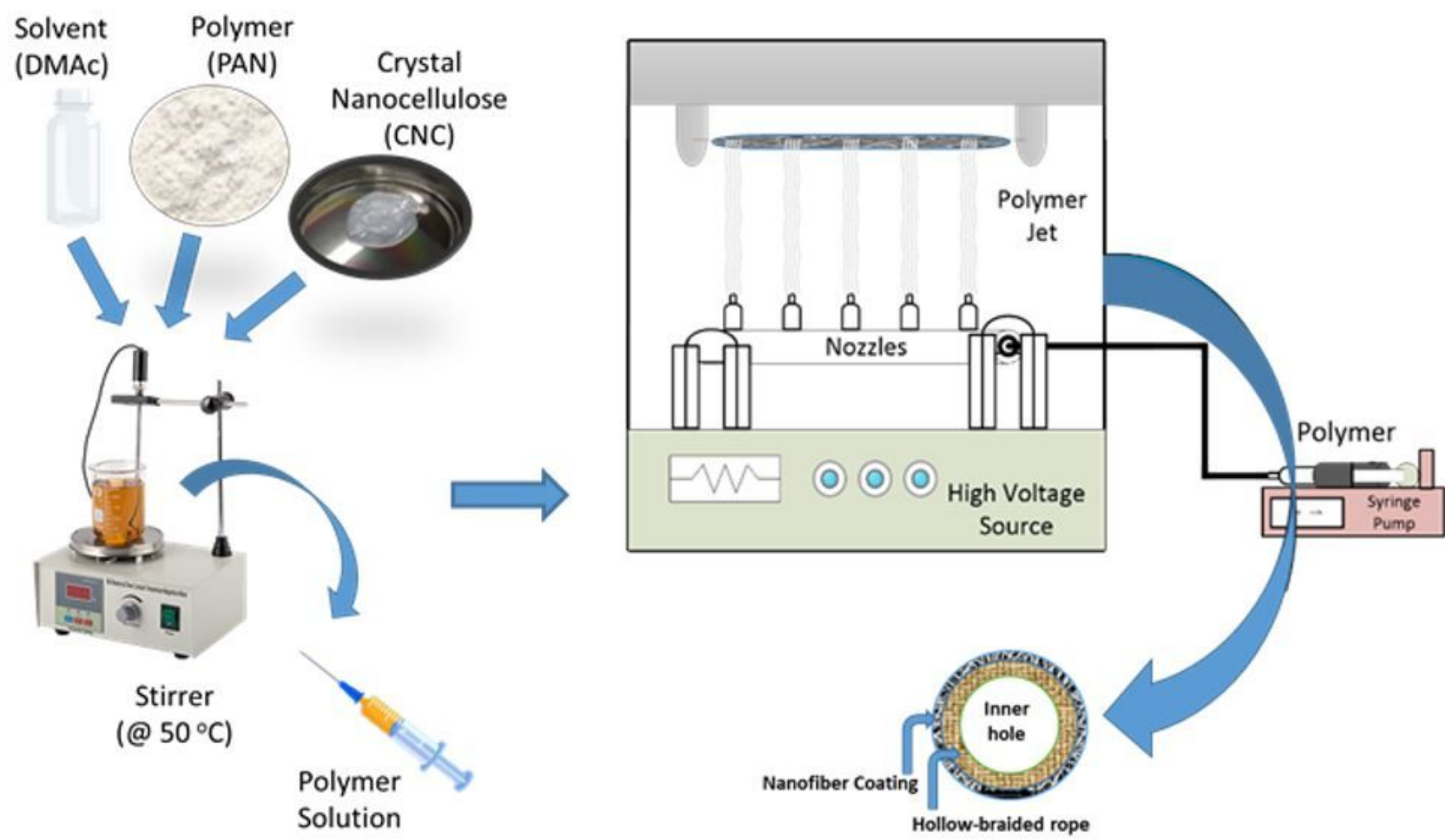

Figure 3

Fabrication steps of nanofibrous tubular mats on hollow braided rope.

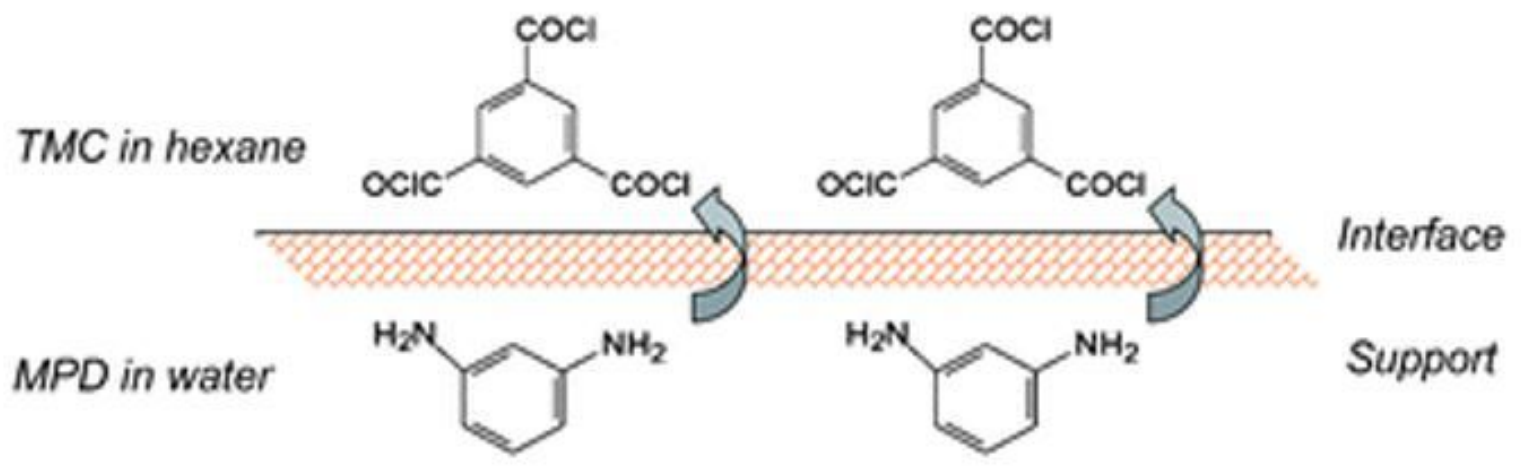

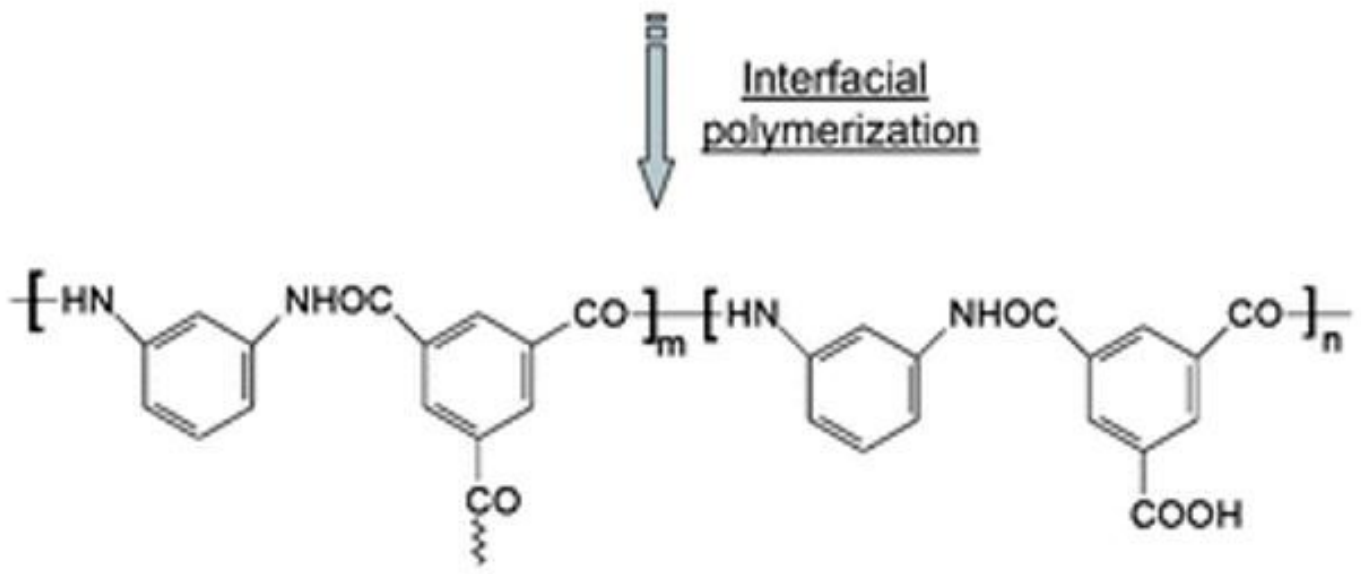




\section{Figure 4}

Interfacial polymerization reaction mechanism to form polyamide (PA) separation layer (Li and Wang, 2010).

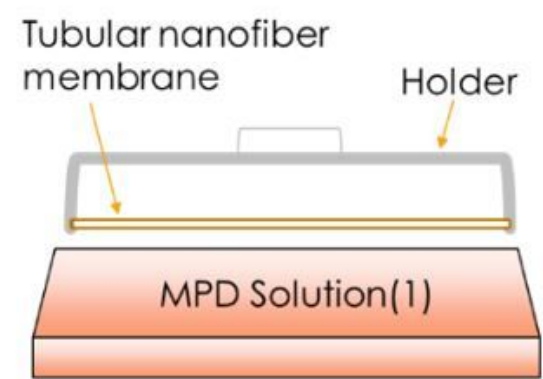

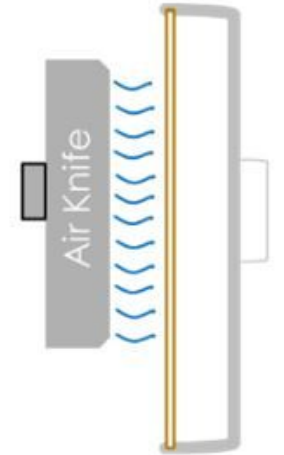

Air Drying (2)

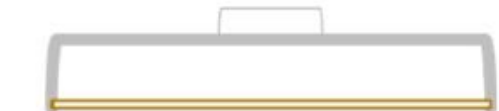

TMC Solution(3)

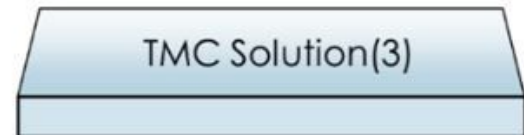

2)

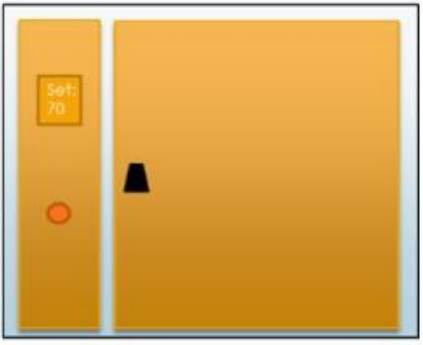

Heat Treatment(4)

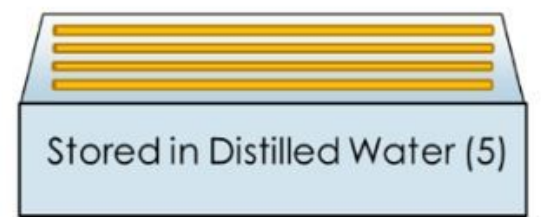

Figure 5

Fabrication steps of nanocomposite (TFN) tubular cnc pressure retarded osmosis membranes 


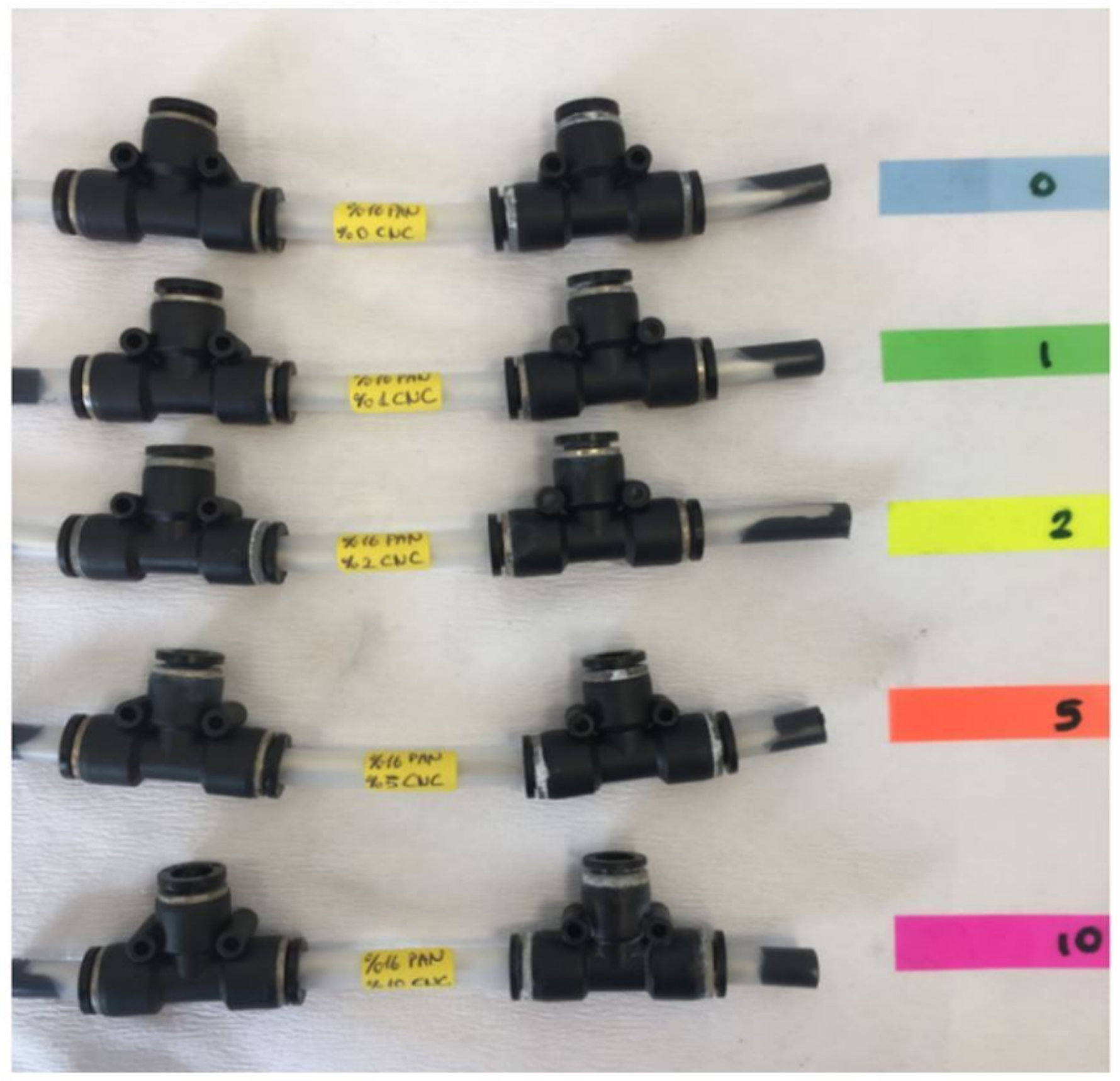

Figure 6

Fabricated PAN/CNC TFN PRO membrane modules 


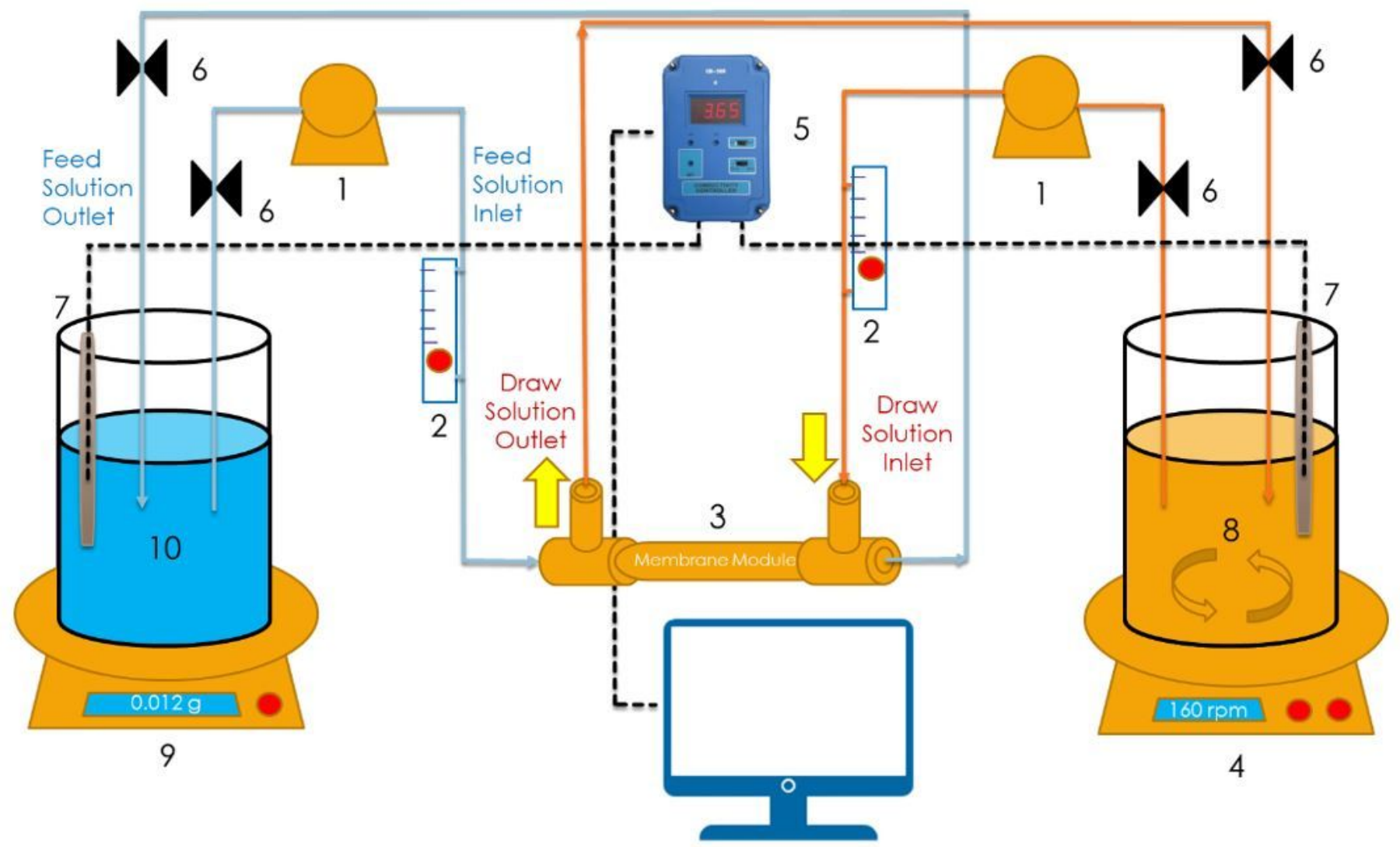

11

Figure 7

Schematic of PRO setup (1) Circulation pump; (2) Flow meter; (3) PRO membrane module; (4) Magnetic stirrer; (5) Conductivity meter; (6) Inlet/Outlet valve; (7) Conductivity meter probe; (8) Draw solution tank; (9) Weighing balance; (10) Feed solution tank; (11) Computer. 


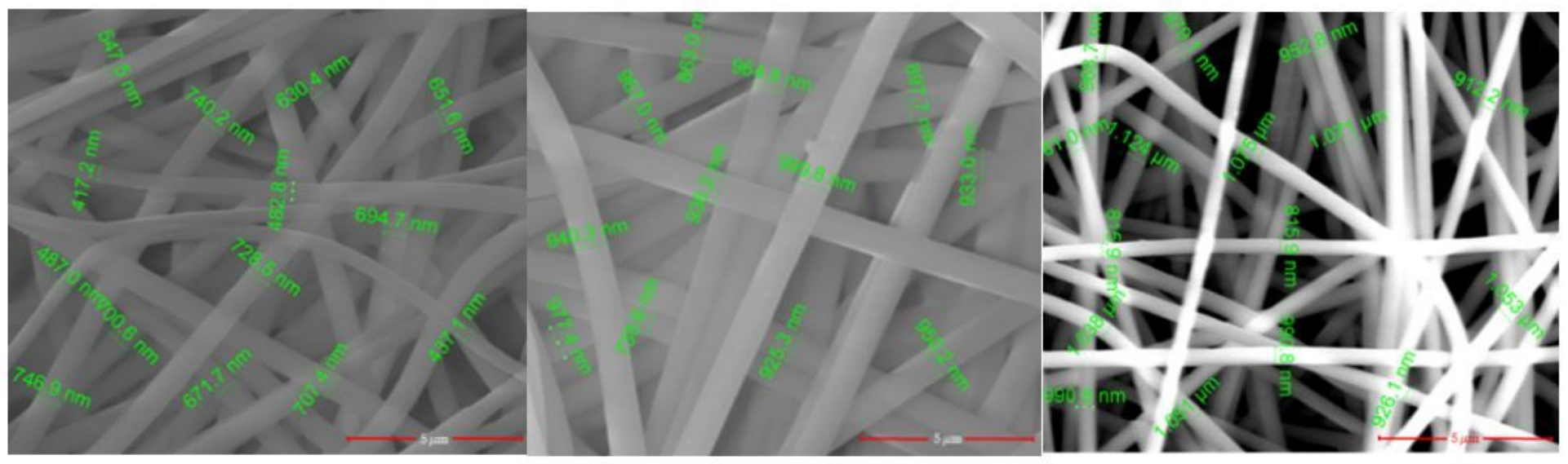
a) $16 \% \mathrm{PAN} 0 \% \mathrm{CNC}$
b) $16 \% \mathrm{PAN} 1 \% \mathrm{CNC}$
c) $16 \% \mathrm{PAN} 2 \% \mathrm{CNC}$

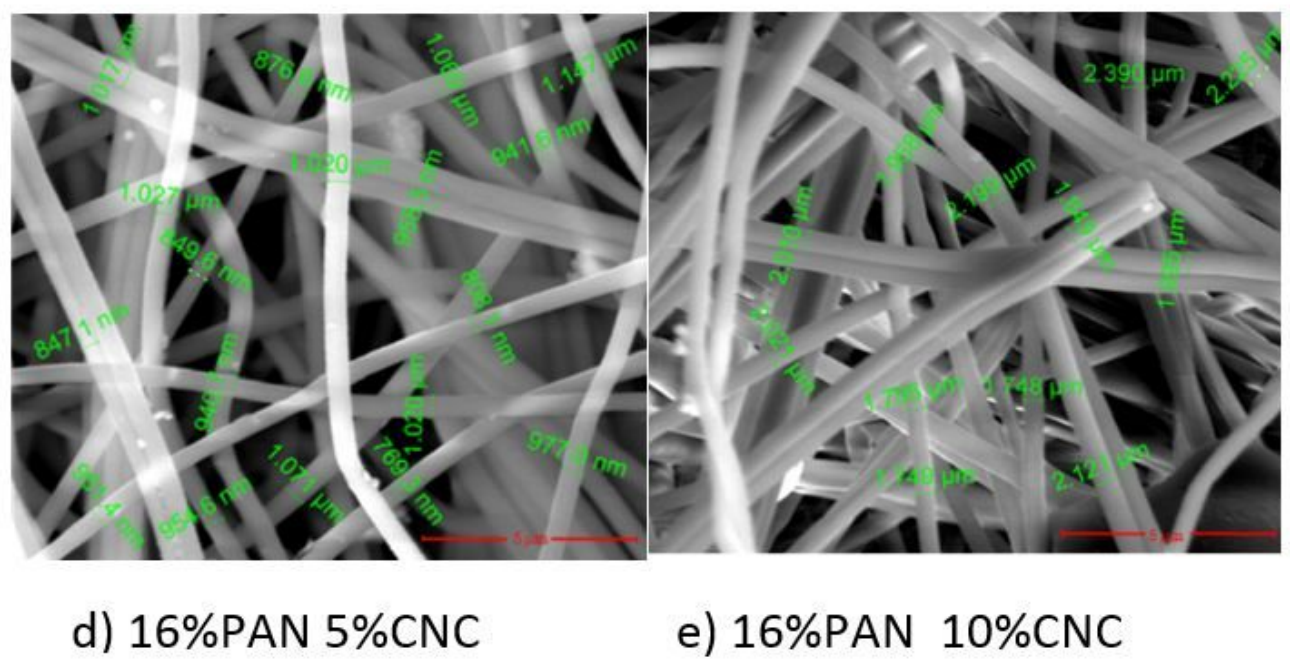

Figure 8

Surface SEM images of tubular nanofibrous support 


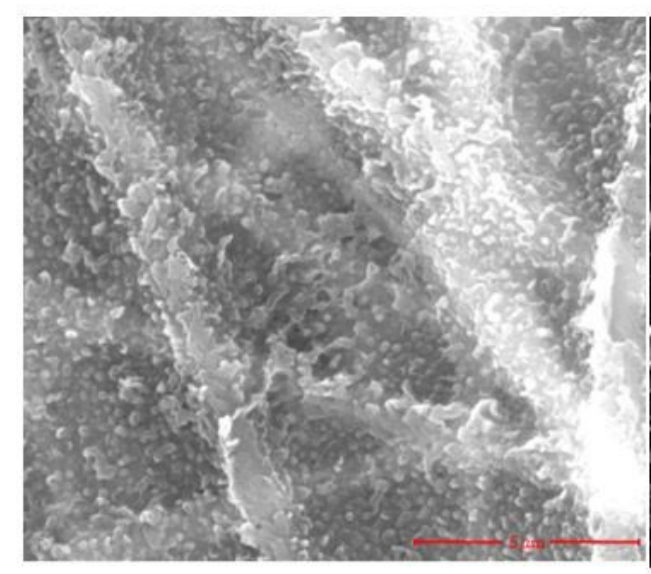

a) $16 \% \mathrm{PAN} 0 \% \mathrm{CNC}$

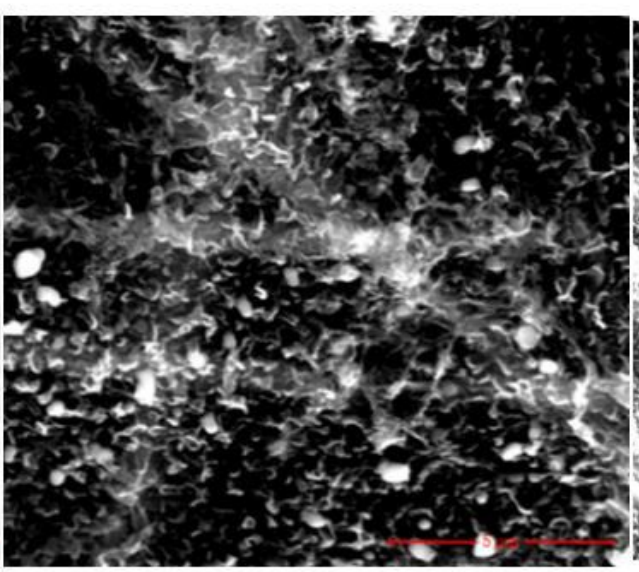

b) $16 \% \mathrm{PAN} 1 \% \mathrm{CNC}$

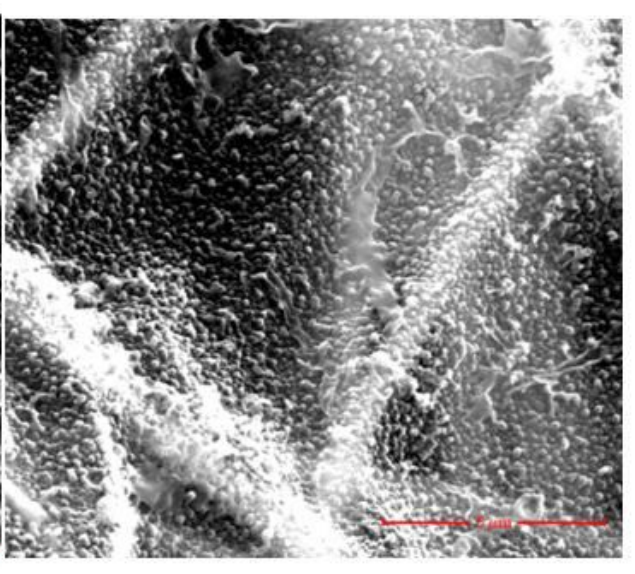

c) $16 \% \mathrm{PAN} 2 \% \mathrm{CNC}$

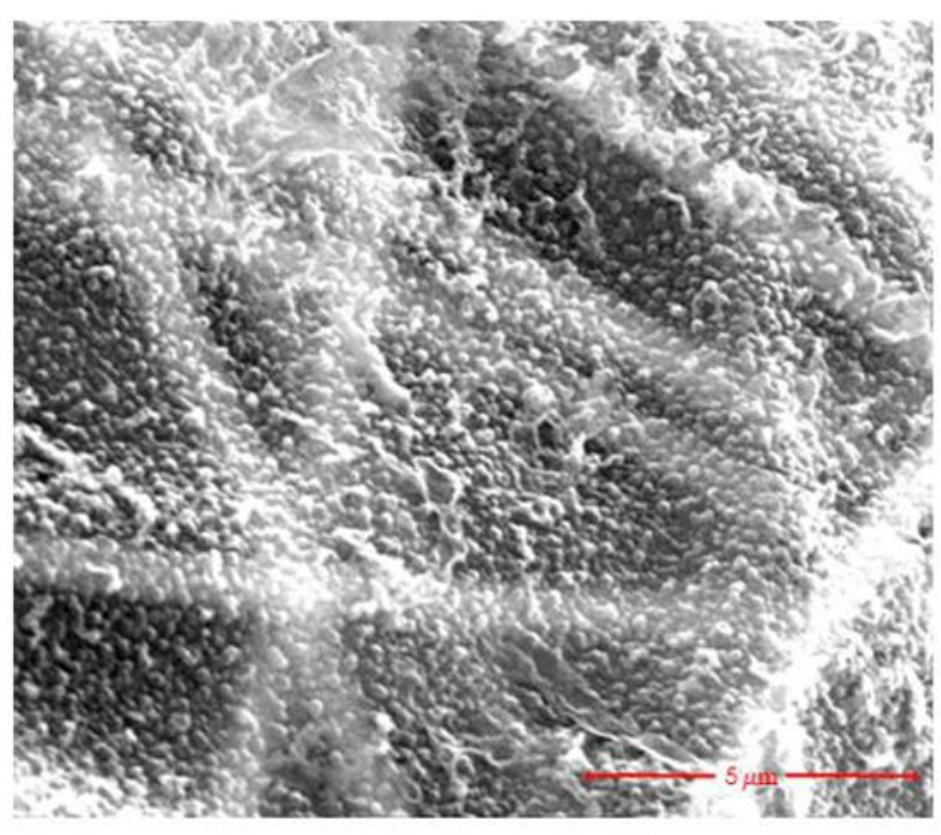

d) $16 \% \mathrm{PAN} 5 \% \mathrm{CNC}$

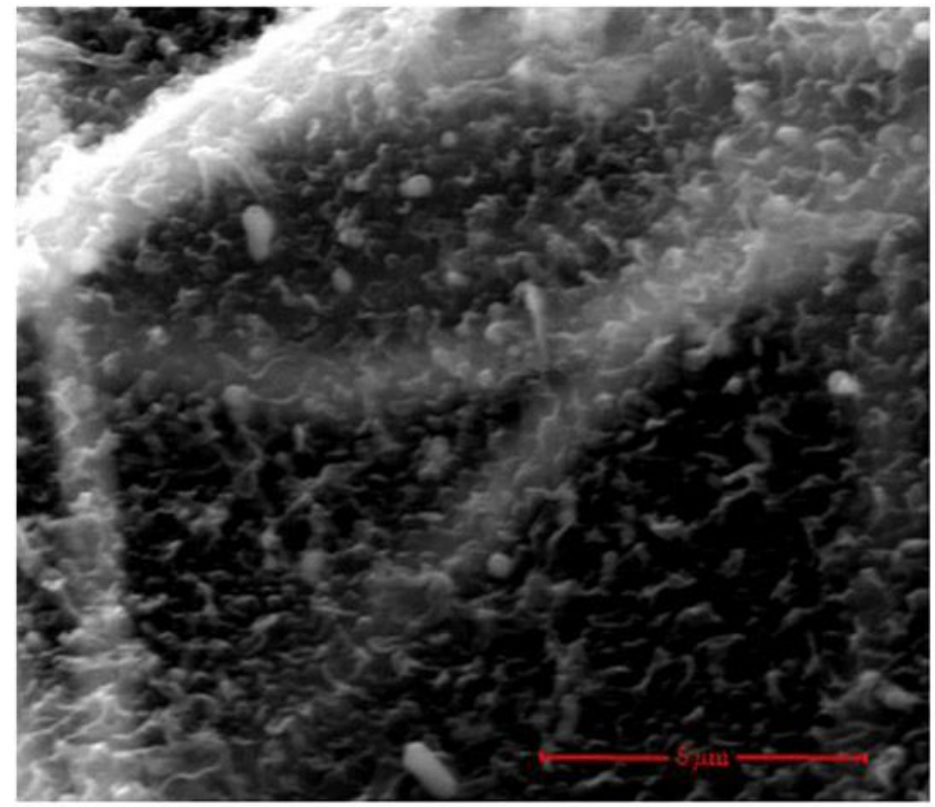

e) $16 \% \mathrm{PAN} 10 \% \mathrm{CNC}$

Figure 9

Surface SEM images of thin film nanocomposite (TFN) layer 

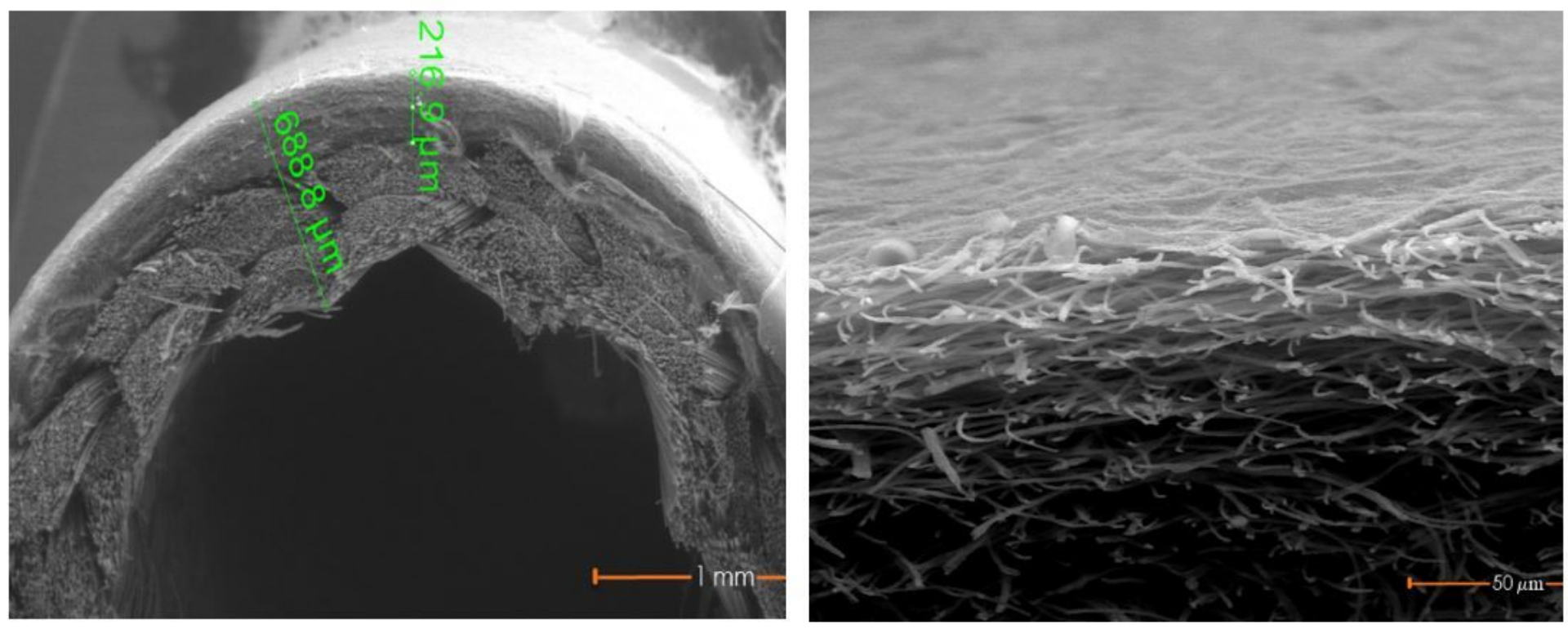

\section{Figure 10}

Cross section SEM images of thin film nanocomposite (TFN) layer

\section{Pore Size Distribution $(\mu \mathrm{m})$}

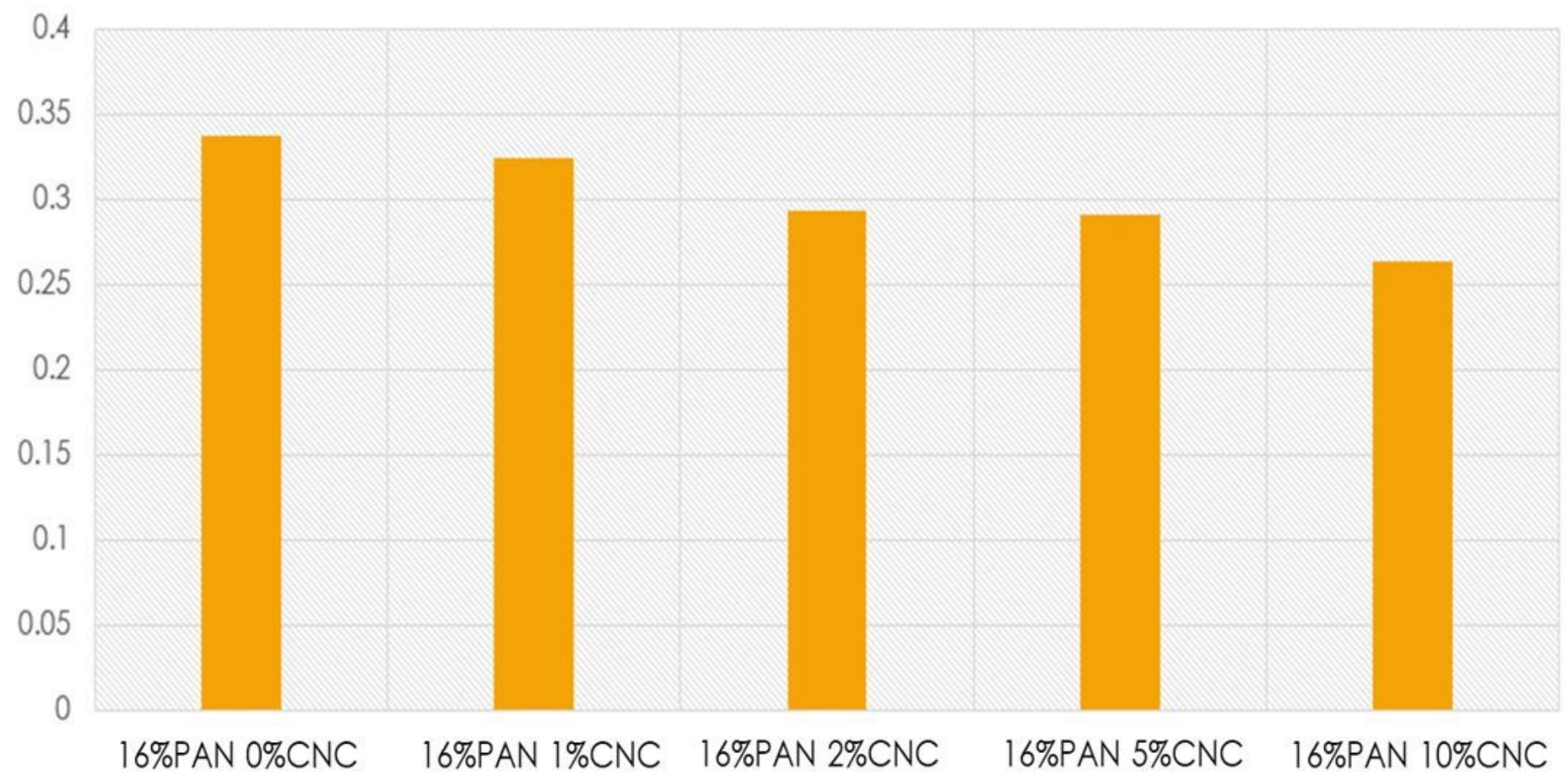

\section{Figure 11}

Average pore size distribution measurement of CNC/PAN nanocomposite nanofibrous membranes 


\section{Youngs' Modulus}

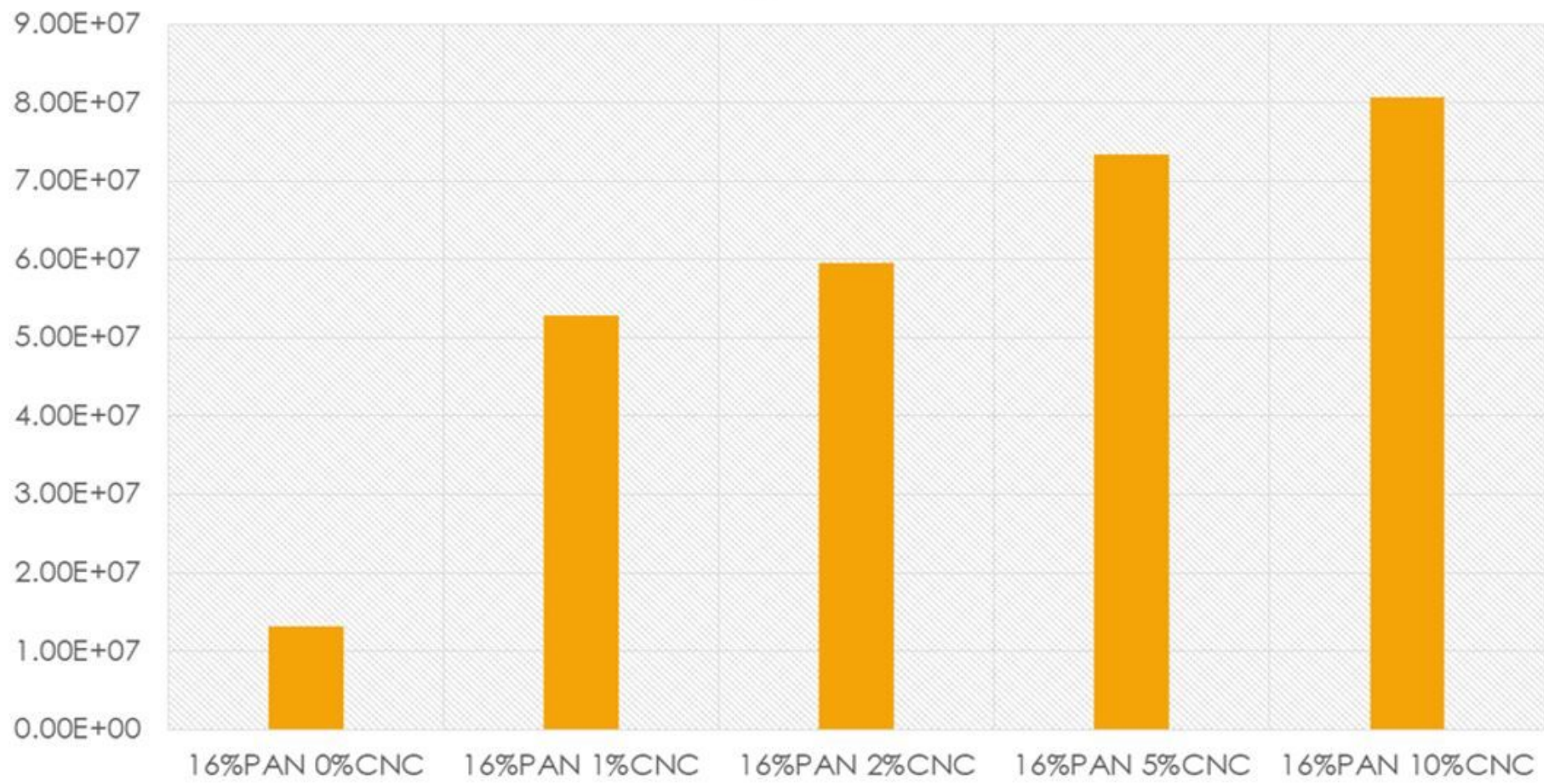

Figure 12

Youngs' modulus of fabricated membranes

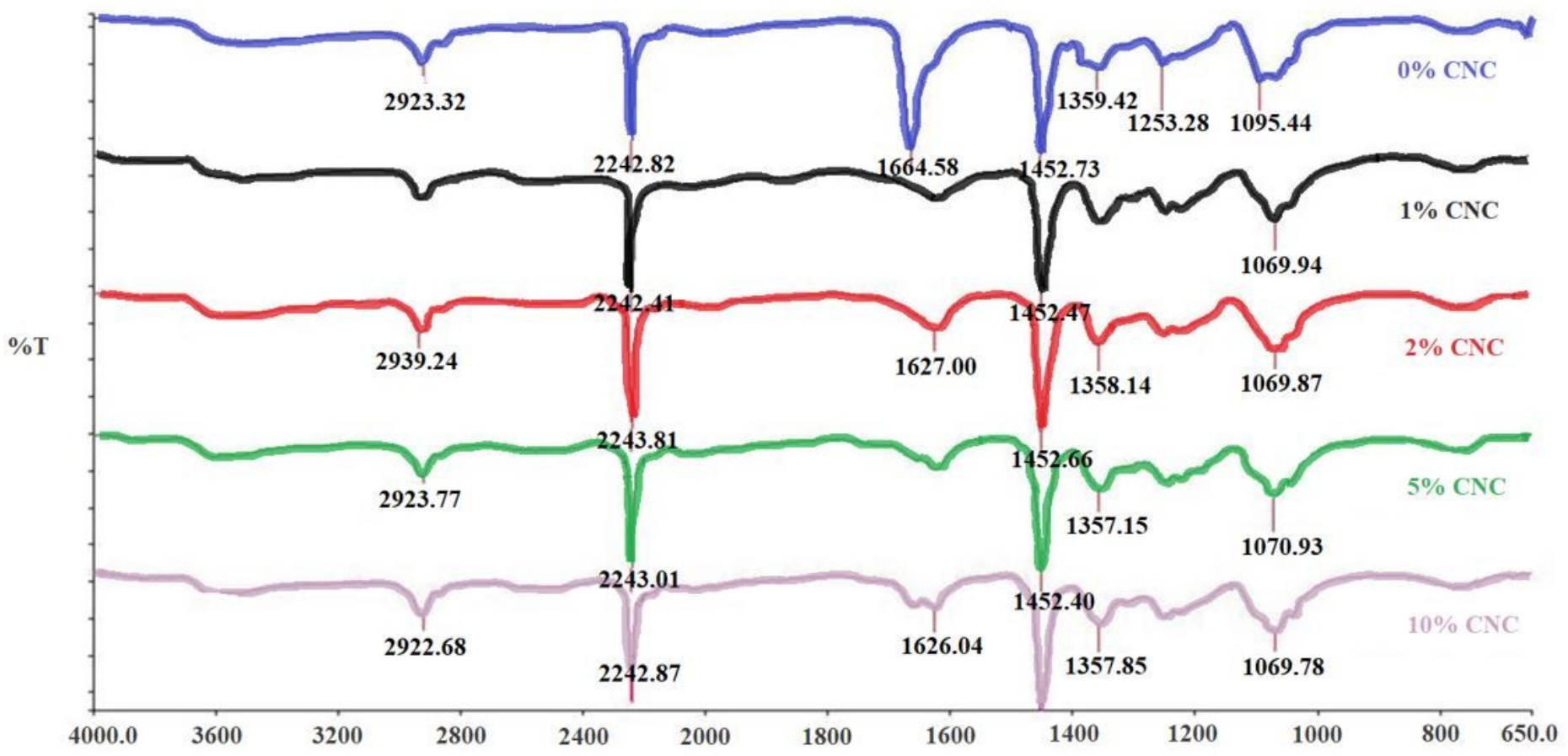

Figure 13

Comparison of FTIR spectra of fabricated membranes 


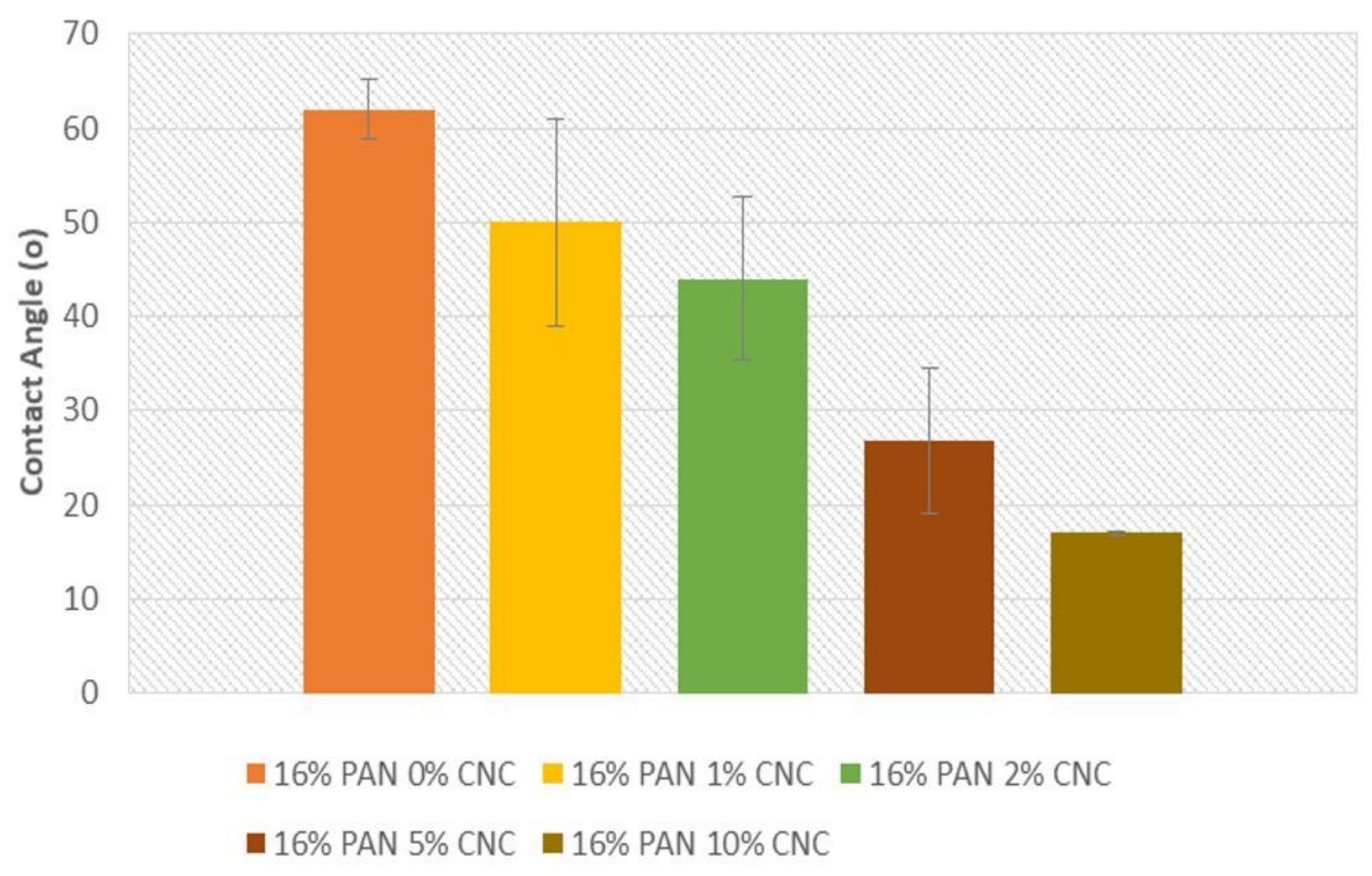

Figure 14

Contact angle comparison of CNC/PAN TFN nanofiber membranes 


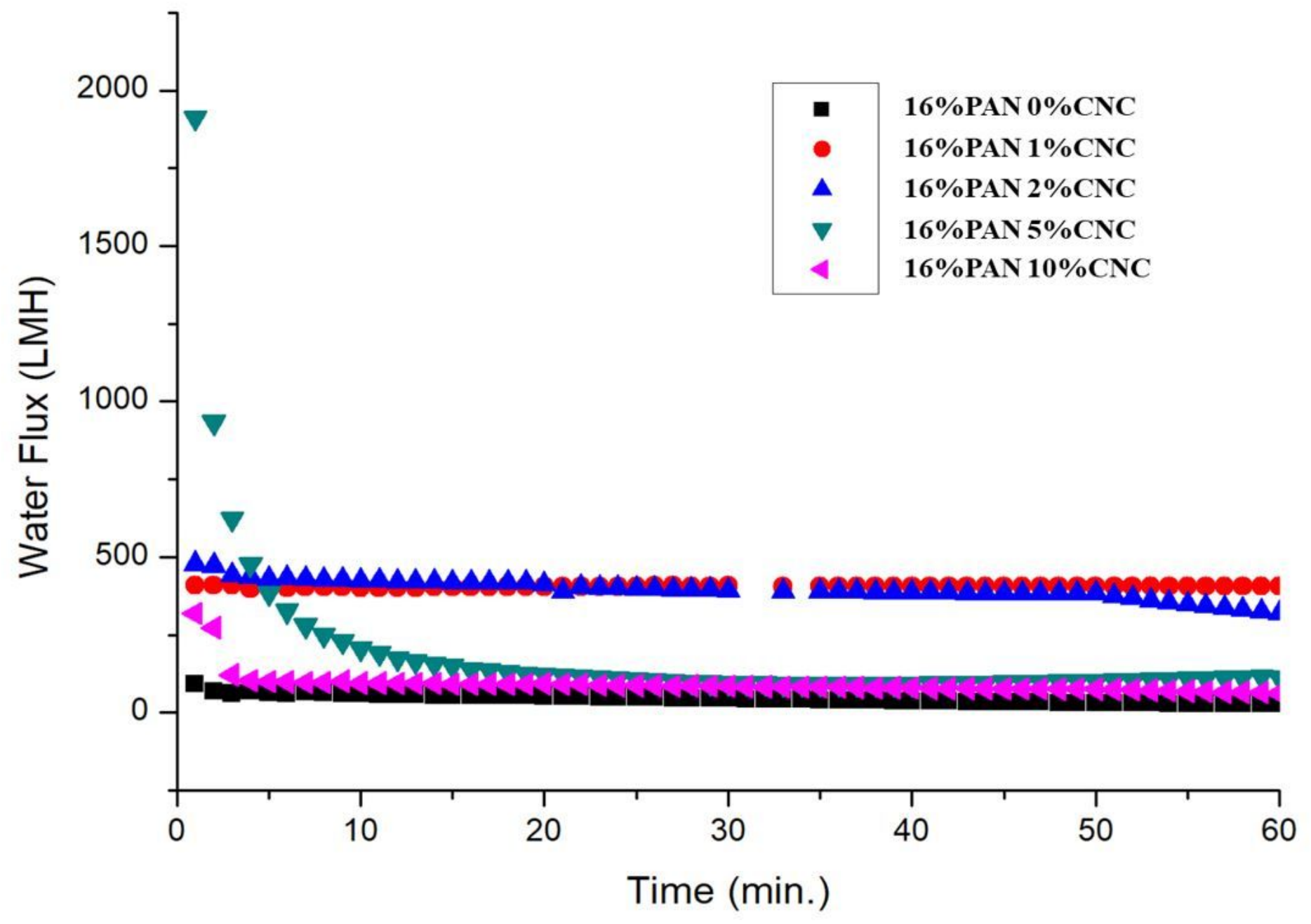

Figure 15

Fabricated PAN/CNC nanocomposite PRO membranes water flux (Jw). 


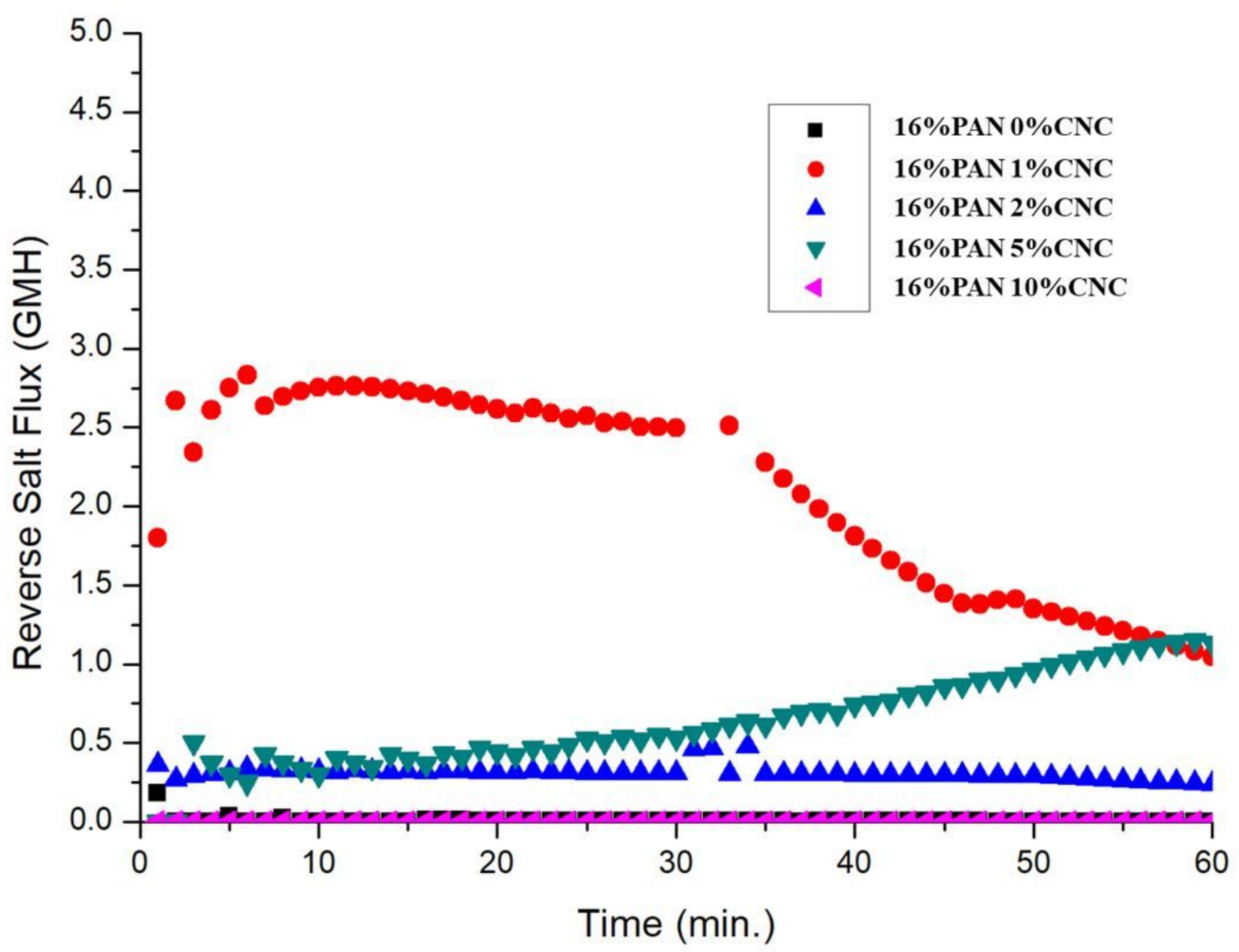

Figure 16

Fabricated PAN/CNC nanocomposite PRO membranes water flux (Js).

\section{Supplementary Files}

This is a list of supplementary files associated with this preprint. Click to download.

- GraphicalAbstract.pdf 